Berkala Ilmu Perpustakaan dan Informasi, Vol. 14, No. 1, Juni 2018, Hal. 26-34 DOI: $10.22146 /$ bip.27502

ISSN 1693-7740 (Print), ISSN 2477-0361 (Online)

Tersedia online di https://jurnal.ugm.ac.id/bip

\title{
User Experience (UX) dalam pemanfaatan fasilitas Informal Learning Space (ILS) perpustakaan
}

\author{
Janu Saptari ${ }^{1}$, Rini Iswandari ${ }^{1}$, Ratna Setyawati ${ }^{1}$ \\ ${ }^{1}$ Perpustakaan Universitas Gadjah Mada \\ Email:janu_s@ugm.ac.id
}

Naskah diterima: 15 Agustus 2017, direvisi: 16 Oktober 2017, disetujui: 23 Januari 2018

\begin{abstract}
ABSTRAK
Pendahuluan. Pengalaman pemustaka (User Experiences, UX) sering kali dijadikan salah satu bahan pertimbangan untuk mengukur kualitas layanan perpustakaan terkait dengan penyediaan fasilitas dan layanan lainnya. Penyediaan layanan ruang baca dan Informal Learning Space (ILS) berupa space di kafetaria, taman, selasar, lobi, dan ruang khusus yang tersedia di dalam area tertentu. Pemanfaatan fasilitas ILS perlu diukur keberhasilannya dengan berdasarkan pengalaman pemustaka.

Metode Pengumpulan Data. Penelitian dilakukan dengan pengumpulan data kuesioner maupun pendekatan wawancara terhadap populasi pemustaka pemakai fasilitas ILS. Populasi yang ditetapkan adalah pemustaka yang sedang menggunakan fasilatas ILS di berbagai area yang tersedia selama satu bulan.

Analisis Data. Data dimasukkan dalam tabulasi excel untuk selanjutnya dilakukan pengolahan. Data rekap dari tabulasi excell dianalisis berdasarkan konstruk penelitian. Dari dianalisis data didapatkan gambaran dari pengalaman pemanfaatan fasilitas ILS perpustakaan.

Hasil dan Pembahasan. Fasilitas ILS digunakan untuk kegiatan studi/akademik. Frekuensi pemakaian ILS setiap hari dengan lama waktu lebih dari 4 jam. Alasan menggunakan ILS karena tersedianya akses internet. Opini terhadap pemanfaatan ILS karena kenyamanan dan lebih produktif.

Kesimpulan. Opini pmanfaatan ILS adalah karena adanya fasilitas internet, kenyaman, dan kerja menjadi lebih produktif, sehingga fasilitas ILS digunakan pemustaka setiap hari dalam waktu yang cukup lama.
\end{abstract}

Kata kunci: Pengalaman pemustaka, User Experience, ruang belajar, Informal Learning Space, ILS.

\begin{abstract}
Introduction. User Experience (UX) is often used as a consideration to measure the quality of library services related to the provision of other facilities and services. The provision of reading room service and informal learning space (ILS) is space in cafeteria, park, hall, lobby, and special room available in certain area. Utilization of ILS facilities needs to be measured for success based on user experience.

Data Collection Method. The research was conducted by collecting questionnaires data and interview approach toward user population of ILS facility. The specified population is the user who is using the ILSfacility in various areas available for one month.

Data analysis. The data are included in the excel tabulation for further processing. Data from the excell tabulation were analyzed based on the research construct. From the analyzed data obtained an overview of the experience of utilization ILS library facilities.

Results and Discussions. ILS facilities are used for study/academic activities. Frequency of use of ILS every day with a duration longer than 4 hours. Reasons for using ILS due to the availability of internet access. Opinion on the use of ILS due to convenience and more productive.

Conclusion. The ILS utilization is due to the fact that internet facilities, comfort, and work are more productive, so ILSfacilities are used every day for a long time.
\end{abstract}

Keywords: User experience, UX, learning space, informal learning space, ILS. 


\section{A. PENDAhuluan}

Undang-undang nomor 43 tahun 2007 pasal 3 menyatakan bahwa perpustakaan berfungsi sebagai wahana pendidikan, penelitian, pelestarian, informasi dan rekreasi untuk meningkatkan kecerdasan dan keberdayaan bangsa. Selain itu perpustakaan dikenal juga sebagai "jantungnya universitas". Dengan demikian aktivitas di perpustakaan tidak dapat dipisahkan dengan proses kegiatan belajar mengajar di lingkungan perguruan tinggi. Aktivitas yang ada di dalam lingkungan perpustakaan perguruan tinggi antara lain mencari sumber informasi, membaca, belajar, diskusi kelompok, workshop, seminar, akses internet dan aktivitas akademik lainnya. Sumber informasi yang diperoleh di perpustakaan kemudian dibaca dan dipelajari lebih mendalam baik di dalam perpustakaan maupun di luar perpustakaan.

Kegiatan membaca/belajar memerlukan tempat khusus di perpustakaan yang biasa disebut sebagai ruang belajar. Ada kalanya pemustaka menggunakan ruang lain yang secara khusus bukan sebagai ruang belajar, tetapi ruang yang dapat difungsikan dan sering dimanfaatkan sebagai ruang untuk belajar. Ruang seperti ini disebut sebagai Informal Learning Space (ILS)/Ruang Belajar Informal.

Sejak perpustakaan memberikan akses layanan $24 \mathrm{x} 7 \mathrm{jam} / \mathrm{minggu}$ dengan multi fungsi layanan seperti akses wifi, website, web-OPAC dan sebagainya, mendorong pemustaka untuk memanfaatkan Informal Learning Space untuk keperluan belajar atau keperluan akademik lainnya. Sekarang ini fungsi ILS hampir sama formal learning space (ruang belajar formal) dalam kehidupannya seperti dinyatakan Brown dan Lippincott (2003) bahwa belajar selanjutnya adalah mendapatkan tempat di luar dan Lippincott (2003) bahwa belajar selanjutnya adalah mendapatkan tempat di luar waktu kelas dari sebelumnya. Hal ini sangat penting untuk menentukan penggunaan konsep baru, seperti ILS pada level yang lebih luas.

Ruang belajar yang tersedia di perpustakaan bermacam-macam model dan jenisnya. Masingmasing mempunyai ciri khas atau karakteristik yang berbeda antara satu dan lainnya. Ruang belajar formal dan informal yang disediakan oleh perpustakaan sesuai perkembangan jaman mengalami perubahan bentuk design, model, sifat dan karakteristik. Agar pemustaka selama dan setelah memanfaatkan fasilitas ruang belajar mendapatkan pengalaman, kenyaman dan kepuasan, maka perpustakaan dalam menyediakan ruang belajar perlu berorientasi pada pemustaka. Pengalaman yang dirasakan oleh pemustaka dalam hal pemanfaatan fasilitas dan layanan ini dikenal dengan istilah pengalaman pemustaka (User Experiences).

Pengalaman yang dirasakan oleh para pemustaka ketika memanfaatkan layanan dan fasilitas ILS yang disediakan perpustakaan UGM perlu mendapatkan perhatian. Pengalaman pemustaka yang baik diharapkan dapat menyebabkan para pemustaka betah ketika memanfaatkan layanan dan fasilitas di perpustakaan. Di samping itu pengalaman baik yang dirasakan oleh pemustaka diharapkan dapat membantu dalam aktivitas belajar dan program akademiknya. Dengan demikian maka perpustakaan yang berfungsi sebagai wahana pendidikan, penelitian, pelestarian, informasi dan rekreasi untuk meningkatkan kecerdasan dan keberdayaan bangsa menjadi kenyataan.

Perpustakaan perguruan tinggi yang merupakan bagian penting dalam kegiatan belajar mengajar, tidak cukup hanya menyediakan kebutuhan sumber daya informasi dan pengetahuan. Akan tetapi perpustakaan juga menyediakan fasilitas yang dapat dimanfaatkan untuk kegiatan belajar-mengajar dan kegiatan akademik lainnya.

Kemudian, bagaimana pengelola perpustakaan perguruan tinggi dalam menghadapi fenomena tersebut? Salah satu jawaban yang dapat diberikan adalah penerapan konsep/pendekatan pengalaman pemustaka (User Experience), yaitu sebuah sikap, tingkah laku dan emosi pemustaka saat dan setelah menggunakan suatu produk, sistem atau jasa/layanan.

Steve Jobs (1997) mengatakan: "you've got to start with the customer experience and work back toward the technology - not the other way around." "Customers don't want products or services, they want experiences" (Anda harus 
mulai dengan pengalaman pelanggan dan bekerja kembali ke teknologi tidak sebaliknya. Pelanggan tidak ingin produk atau jasa, mereka ingin pengalaman). Hunter (2013) dalam penelitiannya menemukan bahwa fasilitas "coffee bar" yang ada di perpustakaan dapat menjadikan salah satu pilihan favorit untuk mendukung kegiatan membaca dan belajar. Begitu juga McArthur (2015) dalam penelitian tentang keberhasilan dan kenyamanan layanan perpustakaan berdasarkan konsep pengalaman pemustaka(UX).

Penelitian yang menyangkut tema pengalaman pemustaka (User Experience) dan ruang belajar dan Informal Learning Space (ILS) telah banyak dilakukan, baik di Indonesia maupun di luar negeri. Penelitian yang telah dilakukan di antaranya sebagai berikut.

Riesmaya (2013) dalam penelitiannya berjudul "Dimensi Kualitas Ruang Perpustakaan" menggunakan teori 10 dimensi kualitas ruangan Andrew McDonald. 10 segi dimensi kenyaman ruang yang dimaksud adalah: functional, environtmentally suitable, adaptable, accessible, varried, interactive, condussive, safe and secure, efficient, dan suitable for information technology. Prasetyawati (2016) dalam penelitian berjudul "Kepuasan mahasiswa terhadap ruang belajar terbuka di Universitas Negeri Yogyakarta", ditemukan bahwa dari sisi fitur pelengkap, desain, estetika, kenyamanan dan kondisi fisik/lingkungan mayoritas pengguna merasakan puas terhadap penyediaan fasilitas ruang belajar terbuka untuk mendukung aktifivitas belajar. Hasil penelitian Burn (2016) dalam "Capturing the student user experience (UX) in York and Loughborough University Library buildings menunjukkan bahwa penggunaan ruang perpustakaan sejalan dengan kelompok user tertentu yang memanfaatkan space dan tujuan mereka datang ke perpustakaan. Hunter, Jonathan and Cox, Andrew (2013) dalam "Learning over tea! Studying in informal learning spaces" menemukan bahwa penggunaan fasilitas ruang belajar dengan suasana yang luas/besar dapat mempengaruhi pilihan terhadap lokasi ruang belajar dan pengguanaan perangkat teknologi miliknya secara hemat. Kemudian juga ditemukan bahwa pemustaka mulai beradaptasi terhadap kebiasaan belajar yang disukai. Kumar, Amit and Bhatt, R.K. (2015) dalam " $A$ Study of Using Informal Learning Spaces at Indian Institute of Technology, Delhi" menyatakan bahwa mayoritas pengguna fasilitas ILS perpustakaan tersebut menggunakan ILS untuk keperluan yang berhubungan dengan akademik dan merasakan bahwa perpustakaan memainkan peranan penting di dalam membuat mereka menggunakan fasilitas ILS. Cunningham, Matthew and Walton, Graham (2015) dalam "Informal learning spaces (ILS) in university libraries and their campuses: A Loughborough University case study" menemukan fakta bahwa persamaan dan perbedaan ILS antara di dalam perpustakaan dan kampus adalah dalam cara mahasiswa menggunakan fasilitas ILS perpustakaan dibandingkan dengan fasilitas ILS di luar perpustakaan (tetapi masih di lingkup kampus), termasuk juga akibat posisi geografis kampus dan tingkat semester mahasiswa. Harrop, Deborah and Turpin, Bea (2013) dalam "A Study Exploring Learners' Informal Learning Space Behaviors, Attitudes, and Preferences" menjelaskan bahwa tipologi dari desain ILS mempunyai 9 atribut sebagai berikut: destination, identity, conversations, community, retreat, timely, human factors, resources, dan refreshment.

Setelah memperhatikan beberapa penelitian dan kajian di atas, maka pada penelitian ini dikaji tentang opini dan pengalaman pemustaka dalam memanfaatkan fasilitas ILS Perpustakaan UGM. Untuk itu, dalam penelitian ini bertujuan untuk mendeskripsikan tentang pengalaman pemustaka (User Experience) meliputi sikap, kesan, pengalaman, respon dan kepuasan serta karakteristik fasilitas Informal Learning Space (ILS) Perpustakaan UGM. Namun secara khusus penelitian ini bertujuan untuk memperoleh informasi dan kejelasan tentang beberapa hal sebagai berikut: 1). Mengetahui opini pemustaka dalam pemanfaatan ILS, 2). Mengetahui frekuensi dan lama pemustaka menggunakan ILS, 3). Mengetahui opini 
pemustaka terhadap fungsi ILS, 4). Mengetahui alasan pemustaka menggunakan ILS, dan 5). Mengetahui dampak menggunakan ILS

\section{B. TINJAUAN PUSTAKA}

1. Pengalaman Pemustaka (User Experience, $U X)$

Istilah pengalaman pemustaka (User Experience, $U X)$ digunakan pertama kali oleh Don Norman, akademisi bidang cognitive science, design dan usability engineering dan mantan vice president Apple Inc., sekaligus penggagas awal dari user-centered design yakni pendekatan desain yang berfokus pada kebutuhan dan keinginan pemustaka. Namun dalam perkembangan selanjutnya penerapan konsep UX semakin luas seperti dalam bidang produk industri, sistem maupun jasa/layanan.

Ada beberapa pendapat tentang pengertian dan konsep UX seperti dalam penjelasan berikut ini. Standar Internasional ISO 9241-211 (edisi revisi) yang bergerak dalam bidang sistem ergonomi interaksi manusia mendefinisikan pengalaman pemustaka $(U X)$ sebagai persepsi dan tanggapan seseorang yang dihasilkan dari penggunaan dari produk, sistem atau jasa/layanan. Menurut definisi ISO 9241-211 dalam Bevan (2015), pengalaman pemustaka (UX) mencakup emosi pengguna, keyakinan, preferensi, persepsi, respon fisik, psikologis, perilaku dan prestasi yang terjadi sebelum, selama dan setelah digunakan.

Pengalaman pemustaka (UX) adalah sikap, tingkah laku dan emosi pemustaka saat menggunakan suatu produk, sistem atau jasa. Pengalaman ini melibatkan persepsi individu berkaitan dengan manfaat yang dirasa, kemudahan yang didapat. UX sangat dinamis, seiring perjalanan waktu persepsi yang dirasakan pengguna bisa berubah sejalan berubahnya lingkungan, kebiasaan dan nilainilai (Wikipedia, 2016).

Konsep pengalaman pemustaka pada awalnya lebih ditujukan untuk sebuah aplikasi berbasis komputer, namun sesuai dengan konsep UX maka sesungguhnya penerapannya dapat dilakukan pada produk, jasa dan ruang fisik. Sebagaimana dinyatakan oleh McArthur (2015) bahwa meskipun Don Norman membatasi tiga tingkat desain produk, akan tetapi tingkat desain ini juga berlaku untuk ruang fisik (dalam hal ini Informal Learning Space). Don Norman bahkan menyatakan bahwa, "mungkin yang lebih penting (dari produk), bagaimanapun, adalah keterikatan pada tempat: sudut favorit rumah kita, lokasi favorit, pemandangan favorit". Perpustakaan juga tempat favorit dan terkait dengan kenangan dan perasaan. Keterikatan yang diasosiasikan dengan ruang adalah dorongan untuk menerapkan teori Don Norman (User Experrience, UX) pada perpustakaan dan fisik ruang lainnya.

Dalam tulisan ini, konteks pengalaman pengguna $(U X)$ yang dimaksud adalah bentuk interaksi antara pemustaka (pengguna perpustakaan) dengan fasilitas Informal Learning Space (ILS), serta layanan/jasa yang menyertainya di perpustakaan perguruan tinggi. Dengan demikian maka UX di sini berkaitan dengan apa yang dirasakan oleh pemustaka yang berhubungan dengan kemudahanan, kenyamanan, efisiensi dan kemanfaatan saat dan setelah menggunakan fasilitas belajar berupa ruang belajar informal.

\section{Manfaat dari Pengalaman Pemustaka (User Experience, $U X$ )}

Norman dalam Allanwood dan Beare (2014) mengatakan: "It's not enough that we build products that function, that are understandable and usable, we also need to build products that bring joy and excitement, pleasure and fun, and yes, beauty to people's lives". Pernyataan ini menegaskan bahwa pada era sekarang ini, tidaklah cukup menciptakan produk yang berfungsi dan dapat digunakan. Suatu produk juga harus membawa kesan menyenangkan dalam kehidupan masyarakat. Adapun manfaat dari UX adalah: 1). Kemudahan bagi pemustaka, 2). Penyediaan fasilitas dan layanan perpustakaan yang menerapkan UX yang baik akan memberi kemudahan dalam penggunaannya, 3). Menaikkan kepercayaan pemustaka, 4). Tingkat kepercayaan pemustaka sangat dipengaruhi oleh kemampuan produk dan layanan yang gunakan dalam membantu menyelesaikan masalah mereka, 5). Menaikkan 
conversion rate, 6). Jika fasilitas dan layanan yang diberikan perpustakaan melalui prosedur dan proses yang sederhana, mudah dan menyenangkan, maka dapat menyebabkan pemustaka merasa senang. Sehingga hal ini akan mengakibatkan semakin banyak pemustaka datang dan memanfaatkan fasilitas dan layanan yang ada, dan 7). Dari segi bisnis UX dipercaya mampu menaikkan pelanggan.

\section{Larning Space (Ruang Belajar)}

Belajar adalah kegiatan utama di perguruan tinggi dan perpustakaan. Belajar dapat dilaksanakan di ruang kelas (pembelajaran secara formal), bisa juga dilakukan di luar kelas (pembelajaran secara informal) yang mengakibatkan terjadiya interaksi antara individu satu dengan yang lain baik secara langsung maupun virtual, serta dengan ruang atau tempat belajar itu sendiri yang membawa pengaruh dalam kegiatan pembelajaran. Kegiatan belajar mengajar di perguruan tinggi banyak mengalami perubahan dan perkembangan. Demi kelancaran proses belajar mengajar, baik dosen maupun mahasiswa memerlukan sebuah ruang atau tempat atau bisa disebut dengan learning space.

Learning space atau ruang belajar dalam konsep modern merupakan sebuah tempat pertemuan yang biasanya menawarkan setidaknya satu area di mana peserta didik dapat mengatur ulang furnitur untuk mengakomodasi diskusi di tempat yang tenang dan nyaman (Educause, 2011). Sedangkan menurut Malcolm B Brown \& Joan K Lippicott dalam Riesmaya (2013), learning space atau ruang belajar merupakan ruang atau area pertemuan peserta didik untuk saling berdiskusi, mengemukakan pendapat tentang tugas atau perkuliahannya, dengan segala fasilitas untuk kenyamanan belajar dilengkapi jaringan atau koneksi internet seperti wifi dan sumber belajar lain untuk memperluas interaksi mahasiswa.

Dahulu, jika berbicara tentang learning space dalam konteks pendidikan, pasti identik dengan sebuah ruang kelas, yaitu ruang yang secara fisik didesain untuk mendukung proses belajar mengajar secara langsung. Ruang kelas itu sendiri banyak mengalami perubahan demi kenyamanan belajar mengajar. Namun karena kapasitas ruang terbatas dan menghindari kejenuhan dalam belajar di dalam ruangan, mahasiswa lebih sering memanfaatkan ruang belajar terbuka seperti foodcourt, kantin atau kafetaria mahasiswa, lobi atau hall kampus, gazebo, student square atau student lounge, dan lain sebagainya. Fasilitas inilah yang dikenal sebagai Informal Learning Space (ILS)

\section{Informal Learning Space (ILS)}

Sebelum mendiskusikan ILS perlu dipahami terlebih dahulu pengertian belajar dan belajar informal. Belajar adalah sebuah proses di mana ilmu pengetahuan diperoleh, dan belajar informal adalah sering diperlakukan sebagai kategori residu untuk menjelaskan beberapa jenis belajar yang mana tidak membutuhkan tempat, atau mengikutinya, sebuah program belajar yang terorganisir secara resmi atau insidental (Eraut, 2000). Dengan demikian maka istilah belajar informal dapat didefinisikan sebagai hasil belajar dari waktu rutin maupun waktu luang lainnya.

Richardson (2004) mendefinisikan belajar informal sebagai kejadian-kejadian di luar sistem pendidikan formal atau pelatihan terstruktur dan tidak diatur secara kualifikatif. Conlon (2003) berpendapat bahwa belajar informal cenderung menjadikan hasil belajar tidak teratur melalui pengalaman setiap hari. Dan sejauh ini ILS adalah ruang yang digunakan di waktu luang seperti taman, kafetaria, dan ruang lainnya diluar kelas/perpustakaan. Jamieson (2013) berpendapat bahwa belajar informal adalah sebuah dorongan belajar atau program yang berdasar studi yang terjadi di luar kelas atau di dalam kelas tetapi di luar jam kelas dengan tidak ada peran pengajar secara langsung. Belajar informal pada lingkungan kampus terjadi di dalam ruang belajar informal (ILS).

Dari perspektif perpustakaan perguruan tinggi, Harrop dan Turpin (2013) melihat bahwa ILS sebagai space/ruang spesifik "nondiscipline" yang sering digunakan oleh kedua pihak staf dan pemustaka untuk mengatur sendiri aktivitas belajar mereka, baik di dalam maupun di luar space perpustakaan. 


\section{METODE PENELITIAN}

Jenis penelitan yang digunakan dalam penelitian ini adalah observasional deskriptif. Populasi dalam penelitian ini adalah pemustaka baik dari sivitas akademika UGM maupun dari luar, yang memanfaatkan fasilitas ILS Perpustakaan UGM. Sementara itu sampel dalam penelitian ini adalah sebagian dari pemustaka yang memafaatkan fasilitas ILS Perpustakaan UGM pada waktu dan tempat/lokasi yang ditentukan (exicental sampling). Jumlah populasi yang tidak diketahui secara pasti (unknown population), cara penentuan besarnya sampel menggunakan rumus seperti dinyatakan Riduwan (2004).

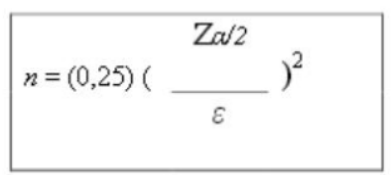

Keterangan :

$\mathrm{n}=$ Jumlah Sampel

$\mathrm{Za}=$ ukuran tingkat kepercayaan dengan $\mathrm{a}=$ 0,05 (tingkat kepercayaan $95 \%$ berarti $95 \% \times 1 / 2=0,475$ dan dalam tabel ditemukan 1,96) $\mathrm{d}=$ Standar Deviasi $(0,25)$ e $=$ Standart error atau kesalahan yang dapat ditoleransi ( $5 \%$ $=0,05$ )

Perhitungan besaran sampel menjadi:

$=((1,96) \times(0,25): 0,05) \times((1,96) \times$ $(0,25): 0,05)$

$=96,04$ dibulatkan menjadi 100 sampel.

Alat yang digunakan dalam penelitian ini adalah kuesioner yang diajukan kepada sejumlah pemustaka yang memanfaatkan fasilitas ILS. Sedangkan bahan yang digunakan adalah data hasil tabulasi pencatatan dari kuesioner.

Penelitian ini dilakukan dengan cara mengambil dan mengumpulkan data berdasarkan kuesioner yang diberikan kepada pemustaka yang sedang menggunakan fasilitas ILS Perpustakaan UGM. Data kemudian dipilih dan dikelompokan berdasarkan: poin-poin konstruk dalam kuesioner. Data selanjutnya dianalisis untuk mendapatkan informasi yang diperlukan. Selanjutnya data hasil analisis disajikan dalam bentuk tabel.

Tempat dan waktu penelitian yaitu di Perpustkaaan UGM di mulai 1 Mei sampai dengan 15 Juli 2017, sedangkan waktu pengambilan sampel data selama 1 bulan.

Dalam penelitian ini kerangka pemikiran penelitian dapat dijelaskan sebagai berikut:

1. Perpustakaan Perguruan Tinggi mempunyai 3 layanan pokok yaitu layanan administrasi, layanan teknis dan layanan pengguna.

2. Layanan administrasi bertugas menjalankan roda administrasi, keuangan, pelaksana penyediaan sarana dan prasarana, dan kepegawaian.

3. Layanan teknik berkaitan dengan pengelolaan bahan pustaka dan pendukung teknis sarana dan prasarana perpustakaan. Layanan pengguna bertugas memberikan layanan kepustakaan dan bantuan lainnya kepada pemustaka.

4. Layanan pemustaka yang ada di perpustakaan meliputi layanan keanggotaan, sirkulasi, referensi, bimbingan pemakai, layanan penelusuran informasi, layanan ruang baca, ruang belajar, ruang diskusi, dan sebagainya.

5. Di antara ruang yang disediakan untuk pemustaka tersebut ada sebagian ruang yang khusus bersifat temporal, santai dan informal yang dapat digunakan untuk aktivitas belajar, interaksi sosial dan keperluan akademik lainnya.

6. Ruang yang dimaksud sebagai konsep Informal Learning Space (ILS) yaitu ruang belajar informal.

7. Penggunaan fasilitas ILS oleh pemustaka selanjutnya akan diukur pemanfaatannya dalam hal respon, kesan, dan pengalaman yang terjadi selama memakai fasilitas ILS berdasarkan konsep User Experience (UX).

\section{HASIL DAN PEMBAHASAN}

Pengambilan sampel data dilakukan di dalam Perpustakaan Pusat UGM. Sampel tersebut diambil dari para pengguna fasilitas informal learning space (ILS) seperti ruang belajar mandiri, ruang diskusi, selasar, lobi, dan taman. Pengambilan data dilakukan dengan cara 
memberikan kuesioner kepada pemakai fasilitas ILS tersebut pada kurun waktu bulan Juni 2017 dengan hasil sebagai berikut.

\section{Profil Responden}

Dari 100 responden teserbut terdiri dari 49 laki-laki dan 51 perempuan. Jika dilihat berdasarkan kategori dari 100 responden terdiri dari 49 mahasiswa diploma/S1, 31 mahasiswa S2, 4 mahasiswa S3 dan 16 tamu (bukan dari mahasiswa UGM).

\section{Opini Pemustaka dalam Pemanfaatan ILS}

Fasilitas ILS perpustakaan digunakan untuk aktivitas yang berhubungan dengan kegiatan akademik yaitu $85 \%$ dan $15 \%$ tidak digunakan untuk kegiatan akademik. Dari $15 \%$ pengguna fasilitas ILS meskipun mereka sedang tidak melakukan aktivitas akademik/studi tetapi mereka mempunyai opini dan menyadari bahwa fasilitas ILS sesungguhnya merupakan tempat/fasilitas untuk aktivitas studi/akademik.

Jika dilihat berdasarkan strata pendidikan maka mahasiswa doktoral 100\% datang ke perpustakaan untuk aktivitas akademik, pascasarjana 94\%, mahasiswa diploma/S1 78\% dan tamu dari luar UGM $85 \%$. Hal ini menunjukkan tren naik berdasarkan jenjang pendikan, artinya semakin tinggi strata pendidikan semakin tinggi aktivitas akademik dilakukan di ILS. Penggambaran fasilitas ILS oleh responden mayoritas yaitu $56 \%$ bahwa ILS itu sebagai ruang belajar yang bersifat individu, sebagai ruang diskusi (17\%), ruang belajar kelompok (14\%), ruang bersantai dan ruang untuk kegiatan bersosialisai (masingmasing 4\%). Pemustaka (S1, S2, S3) mempunyai opini terhadap fungsi ILS sebagai ruang belajar yang bersifat individu yaitu relatif sama antara $67 \%$ untuk diploma/S1, 52\% untuk S2 dan 50\% untuk S3. Hal berbeda pada pengguna ILS dari luar Perpustakaan UGM sebagai tamu hanya pada angka $31 \%$ sebagai ruang belajar individu, 25\% sebagai ruang disksi dan sosialisasi.

\section{Frekuensi dan Waktu Penggunaan ILS}

Frekuensi menggunakan ILS 26\% setiap minggu, 21\% menggunakan 2 hari sekali, $20 \%$ menggunakan jarang, dan $4 \%$ untuk yang belum pernah menggunakan sebelumnya. Frekuensi menggunakan ILS berdasarkan jenjang studi didominasi oleh mahasiswa S3 yaitu 75\% menggunakan setiap hari, mahasiswa S2 29\% setiap hari, $26 \%$ seminggu sekali dan 23\% setiap 2 hari sekali. Mahasiswa S2 menggunakan ILS adalah 29\% setiap hari, 26\% seminggu sekali dan 23\% menggukan dua hari sekali. Mahasiswa diploma/S1 menggunakan ILS $31 \%$ seminggu sekali, $24 \%$ setiap 2 hari sekali. Mahasiswa dari luar UGM yang menggunakan fasilitas ILS Perpustakaan UGM adalah 38\% menyatakan jarang, 19\% menyatakan masing-masing dengan frekuensi 2 minggu sekali dan seminggu sekali.

Lamanya waktu (lebih dari 4 jam) ketika menggunakan fasilitas ILS yang didominiasi oleh pengguna S3 menunjukkan beban kerja studi/akademik yang lebih besar dibandingkan dengan pengguna dengan strata studi S2/S1. Sementara lamanya waktu menggunakan ILS kurang dari 1 atau $1 / 2$ jam ada pada pengguna kategori diploma/S1. Penggunaan ILS yang kurang dari 1 jam sama sekali tidak terjadi pada pengguna ILS S2, S3 dan tamu.

\section{Opini Pemustaka terhadap Fungsi ILS}

Mayoritas (97\%) pengguna fasilitas ILS menyadari bahwa keberadaan ILS setara dengan keberadaan institusi perpustakaan. Sementara yang tidak merasakan arti penting keberadaan ILS hanya $3 \%$. Pengguna kategori S3 dan tamu (pengguna luar UGM) menyadari penuh (100\%) keberadaan ILS tersebut, sementara untuk kategori diploma/S1 dan S2 hanya sedikit saja (4\% dan 3\%) yang menganggap tidak sepenting dengan perpustakaan.

\section{Alasan Pemustaka Menggunakan ILS}

Kecenderungan yang dirasakan ketika pemustaka sedang menggunakan fasiltas 
ILS Perpustakan UGM adalah santai (47\%), kerja lebih produktif $(38 \%)$ dan keadaan fresh (15\%). Jika pengguna ILS dilihat berdasarkan strata studi maka pengguna S3 $100 \%$ merasakan santai. Hal yang berbeda terlihat pada kategori diploma/S1, S2 dan tamu merasakan santai dengan prosentasi yang hampir sama yaitu masing-masing $41 \%$, 48\% dan 50\%. Alasan yang mendorong pengguna memanfaatkan fasilitas ILS adalah karena adanya akses internet gratis, intranet, dan fasilitas yang lebih lama. Namun yang mendominasi dorongan untuk mengunakan ILS Perpustakaan UGM adalah adanya penyediaan akses internet gratis $(37 \%)$. Dengan demikian maka penyediaan akses internet yang baik dan cepat menjadi faktor utama pemustaka memanfaatkan fasilitas ILS.

\section{Dampak Positif dan Negatif Fasilitas ILS}

Dampak positif yang dirasakan pemustaka saat menggunakan fasilitas ILS di Perpustakaan UGM secara umum adalah kenyamanan $(64 \%)$ dan informal $(25 \%)$. Hal ini juga berlaku pada pemustaka berdasarkan tingkat strata pendidikan seperti diploma/S1, S2, S3 dan tamu dengan variasi angka $63 \%, 71 \%, 50 \%$ dan $56 \%$. Hal ini menunjukkan bahwa mereka sudah dapat merasakan dampak positif berupa kenyaman meskipun keadaan kualitas masing-masing fasilitas ILS tersebut berbeda baik kualitas bahan, posisi maupun lokasinya. Dampak negatif yang terjadi yaitu kesibukan ruang (43\%), gangguan $(28 \%)$ dan materi yang tidak tersedia $(21 \%)$.

\section{E. KESIMPULAN}

Pengalaman pemustaka dalam memanfaatkan fasilitas ILS Perpustakaan UGM adalah: pemanfaatan falistas ILS untuk kegiatan akademik, semakin tinggi jenjang studi pemustaka semakin sering menggunakan fasilitas ILS, lama waktu menggunakan ILS lebih dari 3 jam, fungsi ILS setera dengan perpustakaan, alasan menggunakan ILS karena adanya fasilitas internet yang baik, serta dampak positif adalah kenyamanan dan kebebasan penggunaan, sedangkan dampak negatifnya adalah adanya kesibukan dan kebisingan lingkungan. Saran yang perlu peneliti sampaikan: peningkatan penyediaan fasilitas dan peningkatan pemeliharaan terhadap fasilitas ILS.

\section{DAFTAR PUSTAKA}

Bevan, N., Carter, J. \& Harker, S.S. (2015). ISO 9241-11 revised: What have we learnt about usability since 1998?. Human Computer Interaction, Part 1. Diakses 11 September 2017, dari https://pdfs. semanticscholar.org/

Brown, M.B. \& Lippicott, J.K. (2003). Learning spaces: More than meets the eye. Educause. Diakses 20 Maret 20017 , dari http://net.educause.edu/

Burn, K. et al. (2016). Capturing the student user experience (UX) in York and Loughborough University Library buildings. Performance Measurement and Metrics, 17(2), 175-187. DOI 10.1108/PMM-04-2016-0021

Conlon, T. (2003). A review of informal learning literature, theory and implications for practice in developing global professional competence. Journal of European Industrial Training, 28(2/3/4), 283-95. Diakses 11 September 2017, dari https:// media.proquest.com/

Cunningham, M. \& Walton, G. (2016). Informal learning spaces (ILS) in university libraries and their campuses: A Loughborough University case study. New Library World, $117(1 / 2)$, 49-62. DOI 10.1108/NLW-042015-0031

Educause. (2011). 7 things you should know about the modern learning commons. Diakses 11 September 2017, dari https://library.educause.edu/.

Eraut, M. (2000). Non-formal learning and tacit knowledge in professional work. British Journal of Educational Psychology, 70, 113-136. Diakses 20 Maret 2017, dari http://old.mofet.macam.ac.il/iunarchive/mechkar/pdf/Non-formalLearning. pdf 
Harrop, D. \& Turpin, B. (2013). A study exploring learners informal learning space behaviors, attitudes, and preferences. New Review of Academic Librarianship, 19(1), 58-77. DOI: 10.1080/13614533.2013. 740961

Hunter, J. \& Cox, A. (2013). Learning over tea! Studying in informal learning spaces. New Library Worl, 115(1/2), 34-50.

Jamieson, P. (2016). Reimagining space for learning in the university library. User Experience in the Library. Diakses 11 September 2017 , dari https:// www.crcpress.com.

Jobs, S. (1997). World wide developers conference. Diakses 11 September 2017, dari https://en.wikiquote.org/wiki/ Steve Jobs.

Kumar, A. \& Bhat, R.K. (2015). A study of using informal learning spaces at Indian Institute of Technology, Delhi. Library Philosophy and Practice (e-journal). Paper 1239. Diakses 20 Maret 2017, dari htp://digitalcommons.unl.edu/libphilprac/1 239.

Margono, S. (1997). Metodologi penelitian pendidikan. Jakarta: Rineka Cipta.

McArthur, J.A. \& Graham, V.J. (2015). Userexperience design and library spaces: A pathway to innovation? Journal of Library Innovation, 5(2). Diakses 5 Oktober 2017, dari https://sites.google.com/site/ journaloflibraryinnovation/vol-6-no-2-2015.
Nawawi, H.H. (1998). Metode penelitian bidang sosial. Yogyakarta: Gama Press.

Allanwood, G. \& Beare, P.B. (2014). User experience design: Creating design users really love. London: Bedford Square. Diakses 20 Maret 2017, dari https:// books.google.co.id/.

Prasetyawati, R.S. (2016). Kepuasan mahasiswa terhadap ruang belajar terbuka di Universitas Negeri Yogyakarta (Skripsi). Yogyakarta: Fakultas Ilmu Pendidikan UNY.

Richardson, S. (2004). Employers' contribution to training, NCVER, Adelaide. Diakses 11 September 2017, dari http://www.sapo. org.au.

Riduwan (2004). Metode dan teknik menyusun tesis. Bandung: Alfabeta

Riesmaya, V. (2013). Dimensi kualitas ruang perpustakaan. Diakses 27 Maret 2017, dari http://journal. unair.ac.id/.

Santosa, S. (2008). Metode penelitian biomedis 2. Bandung: Danamartha Sejahtera Utama.

Soewadji, Y. (2012). Pengantar metodologi penelitian. Jakarta: Mitra Wacana Media.

Undang-undang Republik Indonesia no. 43 tahun 2007 tentang Perpustakaan.

Wikipedia (2016). User experience. Diakses 22 Maret 2017, dari https://en.wikipedia.org/

Zuriah, N. (2006). Metodologi penelitian sosial dan pendidikan: Teori dan aplikasi. Jakarta: Bumi Aksara. 